\title{
A RIGHT TO GRATITUDE
}

\section{Zbigniew Szawarski*}

\begin{abstract}
Few matters in medical ethics give rise to such passionate disputes and discussions as the issues of doctors' acceptances of diverse kinds of gifts, services or favours from grateful patients or pharmaceutical companies interested in acquiring a physicians endorsement. Gratitude is a fundamental moral value. Modern philosophy proposes three different, rival models of gratitude. Appropriate social rules determine what, when and under what conditions counts as a reciprocation of a gift. The moral sphere between doctor and patient is incredibly complex: there appear to be four types of possible attitudes that a patient can adopt towards a physician. The art of giving is as complex as the art of receiving.
\end{abstract}

Key words: gratitude, social rules, rights, obligations, tact, good taste

\section{DERECHO A LA GRATITUD}

Resumen: Pocos temas de ética médica despiertan tantas apasionadas disputas y discusiones como el de la aceptación, por parte de los médicos, de distintos tipos de regalos, servicios o favores de pacientes agradecidos, o de compañías farmacéuticas interesadas en obtener su visto bueno. La gratitud es un valor moral fundamental. La filosofía moderna propone tres modelos de gratitud, diferentes y rivales. Reglas sociales claras pueden determinar qué, cuándo y bajo cuáles condiciones algo cuenta como reciprocidad a un regalo. La esfera moral entre médico y paciente es increíblemente compleja: existen, aparentemente, cuatro actitudes posibles que un paciente puede adoptar frente a un médico. El arte de dar es tan complejo como el de recibir.

Palabras clave: gratitud, reglas sociales, derechos, obligaciones, tacto, buen gusto

\section{DIREITO À GRATIDÃO}

Resumo: Poucos temas de ética médica despertam tantas e apaixonadas disputas e discussões como o da aceitação, por parte dos médicos, de distintos tipos de presentes, serviços ou favores de pacientes agradecidos ou de indústrias farmacêuticas. A gratidão é um valor moral fundamental. A filosofia moderna propõe três modelos de gratidão, diferentes e rivais. Regras sociais claras podem determinar o que, quando e em que condições algo conta como reciprocidade para um presente. A esfera moral entre médico e pacinte é incrivelmente complexa: existem aparentemente quatro atitudes possíveis que um pacinte pode adotar frente a um médico. A arte de dar é tão complexa como a de receber.

Palavras chaves: gratidão, regras sociais, direitos, obrigações, tato e bom gosto

* BIBAC Member, Professor, Department of Philosophy, University of Warsaw Correspondence: z.szawarski@uw.edu.pl 
"Of all crimes that human creatures are capable of committing, the most horrid and unnatural is ingratitude..."

David Hume, Treatise on Human Nature, Book III, Part I, Section I.

Physicians have as their patron saints Cosmas and Damian -martyrs who died for their faith in Diocletian's times, ca. 303 A.D. The two men treated their patients completely free of charge. However, as it happened, one day Damian accepted three eggs from a woman by the name of Palladia, because he was unable to tactfully decline her offer. According to legend, the result was so brusque and profound a conflict between the two brothers that it was only the advent of a talking camel that brought it to an end. Since its beginnings medicine has had to deal with the problem of decent compensation and additional gratification for the physician. "The patient has a right to gratitude," say doctors to justify their accepting all kinds of tokens and services - both material and non-material. "The physician has a right to gratitude," claim the patients, utterly convinced that there is nothing morally amiss if they bring their doctor a bottle of cognac, or leave a banknote-filled envelope on his desk. And yet, few matters in medical ethics give rise to such passionate disputes and discussions as the issue of doctors' acceptance of diverse kinds of gifts, services or favours from grateful patients, or pharmaceutical companies interested in acquiring a physician's endorsement. Let us examine what is this peculiar "right to gratitude" which in certain situations magically transforms a rank bribe into a lofty expression of appreciation.

There certainly exist situations in which man ought to show gratitude. Gratitude is a fundamental moral value present in all human societies, with no exceptions. It arises in situations whereby someone has provided us with some good, irrespective of its nature -i.e. irrespective of its being a material gift, or some favour. Plainly, the nature of this good changes depending on the society and historical period; the actual mechanism of gratitude, however, remains the same. It is for this reason that in all historical periods or geographical locations there arise certain clearly defined situations in which we can speak of the feeling of gratitude, debt of gratitude, duty of gratitude, virtue of gratitude, and even -as the Polish context seems to suggest- of the right to gratitude. Still, what is the essence of gratitude?

Let us reiterate, gratitude appears in a situation whereby someone confers upon us some good. However, not every conferral of a good binds us with the duty of gratitude. If somebody provides us with some good only because he likes to give others pleasure, or because it is advantageous for him, or constitutes his professional obligation, or else he is forced to by some other circumstances, then there is no reason for gratitude. I have never heard of or read about a situation where upon receiving absolution in a confessional the penitent would hurry to the presbytery with a dozen eggs, a bottle of cognac or a symbolic envelope. And, after all, acquiring an opportunity for eternal bliss in the heavenly kingdom is incomparably greater a good than keeping an earthly life, as confirmed by the numerous examples of martyrs. Am I really obliged to express special gratitude to a mechanic who just pocketed a heft sum for a periodic check-up of my car? Does the fact that in performing it he was adroit, quick and competent, and additionally quite nice, place upon me some particular duty of gratitude? The man does what he is supposed to do as part of his work contract. I therefore see no important reason for me to show him any extra gratitude. That medicine deals with human life is not a good argument, since the same can be said of 
the car mechanic. A mechanic who fails to notice or fix a faulty break in my car is as responsible for a person's inadvertent death as a physician who commits a diagnostic error or incorrectly evaluates the state of his patient's health. I have never come across a car mechanic who, invoking his "right to gratitude," claimed an extra payment for a well performed checkup. Why is it that the idea of a duty of gratitude so often appears in doctors' consulting rooms and is practically non-existent in other professions? In order to answer this question we must more thoroughly examine the very concept of gratitude.

It is not the case that every act of providing us with some good bestows upon us the duty of gratitude. However, such an obligation does arise in situations where three additional important conditions are satisfied. First, it cannot be just any good; this good has to carry special significance for me. I can, for instance, disregard a pen I received from a representative of a pharmaceutical company, but I would find it difficult to stifle my feeling of gratitude if this company covered my expenses on a trip to Chile to attend an important scientific congress. Second, the act of providing me with this good must require some effort, sacrifice, or renouncement on the part of the provider going beyond what he is normally obliged to do in the given situation. For example, arranging grants to attend some scientific congress is not ordinarily among the duties of the head of a clinic. Were the head of my clinic to devote time and effort, moving heaven and earth for me to be able to participate in a scientific congress in Chile that is of great importance to my research, I would have a debt of gratitude towards him, since what he did for me went well beyond his ordinary professional obligations. I would not be so indebted, however (and this is the third condition), if it so happened that his principal motive to act the way he did was not my personal good, but his own selfish interest, because in sending me to Chile he was buying my loyalty. He does me a favour because he is constructing his private empire of influence and knows that one day (recall Coppola's excellent film "The Godfather") he can demand something in return. Perhaps, if I give it a little more thought, I have no debt of gratitude towards the pharmaceutical company sending me to Chile, since the costs it incurs do not constitute any sacrifice, being simply a rationally planned marketing ploy whose ultimate aim is to increase the company's profits. In doing me a favour the company does not care about my personal good, but only its own selfish interest.

This is not the end of the complications connected with the concept. Although the feeling of gratitude indubitably assumes some connexion between the person who provides the good and the one who receives it, the nature of this connexion remains somewhat unclear.

Modern philosophy proposes three different, rival models of gratitude, which attach completely disparate significance to the different elements of the relation. The first model, drawing on the Humean tradition, considers gratitude as a reaction to another person's disinterested benevolence. The feeling of gratitude and appropriate behaviour related to it thus constitute a natural confirmation of having received the good and having thanked for it. Gratitude is a kind of virtue, a certain ability to behave appropriately in a given situation. Ingratitude is, on the other hand, a repulsive vice, especially when, as Hume writes, it concerns non-fulfilment of our obligations to our parents. The second model, emerging mainly from the ethics of Kant, identifies gratitude with the absolute duty to settle one's debts. Upon receiving from someone some good of great importance to me, 
I take on a debt of gratitude which absolutely must be repaid. The form of repayment naturally depends on my situation, but a debt is a debt, and I cannot be a good and decent person if I don't pay my dues. The third model of gratitude refers primarily to the anthropology of gift and the principle of reciprocity - do ut des (I give that you may give). Good is to be reciprocated with good, evil with evil. So, if I was provided with some good (favour), I have an absolute obligation to reciprocate. Appropriate social rules determine what, when and under what conditions counts as reciprocation of a gift. Inability to reciprocate evokes in a person the feeling of guilt for not fulfilling the duty of gratitude. As an aside, it should be noted that in this model much depends on what is counted as a gift. Can, for instance, life be considered a gift, as suggested by the common idiom "the gift of life"? One of the most peculiar critical arguments against transplants is that since it is impossible to morally repay the gift of an organ (e.g. the gift of a heart), it becomes a poisoned token, leaving the patient with the feeling of unsettled debt and permanent guilt. For how can one genuinely repay the gift of life?

\section{Gratitude and medicine}

It may seem enough to apply any of the described models of gratitude to the doctorpatient situation to see a complex system of relations between the two parties take shape. This is not the case. Despite the fact that the structure of mutual relations emerges clearly the doctor is the purveyor of the good, the patient is the recipient, and the good can be a great many things, from saving the patient's life to helping him acquire undeserved disability benefit or exemption from military draft - what actually occurs in the moral sphere between doctor and patient is incredibly complex and it is not easy to extract what does in fact deserve gratitude from the tangle of incentives and motives of conduct. Notice that physicians' activity is not an act of disinterested benevolence towards another person. A young adept of medicine does not study laboriously all his life in order to selflessly help everyone around. Treating a patient is a normal job, and in normal circumstances it requires no sacrifice or heroism. Patient thus has no debt of gratitude towards someone who more or less adroitly fulfils his everyday professional obligations. Moreover, there are known cases where the principal motive for choosing the medical career is ordinary prudence and a desire for decent remuneration. It is said that people will always fall ill. A physician will never starve to death. What reasons can there be for expressing extra gratitude towards someone who lives off my fear, pain and suffering.

In normal circumstances the feeling of gratitude usually emerges in a situation characterised by ideal symmetry between two people. You scratched my back today, I'll scratch yours tomorrow. Recompense, payback, reciprocity, expressions of gratitude, ordinary thanks, or however else we label our reaction to the received good, constitute a spontaneous human response. They are the confirmation that we have experienced benevolence, and at the same time that we accept the obligation to the effect that in a similar situation we shall attempt to act just as considerate, kind, disinterested or altruistic a manner. Nonetheless, when we try to examine what happens in a consulting room from this perspective, it turns out that the relation between doctor and patient is inherently asymmetrical. A physician is not just any other person, like me, or you, or her. A physician is a person endowed with special powers - knowledge of what is the cause of my ills, and of how to help me. The doctor is the absolute master of the situation - it is he who conducts the interview, poses intimate questions, tells others 
to do this or that, or performs complicated surgical procedures. The relation between doctor and patient is a relation between the one who acts (the agent), and the one who is subject of this act (patient). If a doctor's knowledge and skills are used properly and the patient returns to health, the latter can justifiably feel gratitude. If, however, the doctor, for some justified reasons or due to some subjectively error is unable to help, or worse, hurts the patient, it is understandable that the latter will feel greatly disappointed, and may even show signs of aggression towards the physician.

Aside from asymmetry, an additional factor complicates the moral psychology of doctorpatient relations, namely the fact that in our society the physician's social role is strongly institutionalized and subject to determinate legal regulations. Hence, the relation between doctor and patient is not a chance encounter of two people, of which one requires help, and the other is able to provide it. It is a kind of contract, whereby the two parties accept certain rights and obligations. The sphere of doctor's rights and obligations is determined by culturespecific morality and law regulating the medical profession, as well as his country's existing healthcare system. With the patient, the emphasis falls especially on his rights, for he is by nature a frail, defenceless creature, struck by illness and, above all, in need of help. This does not imply that he has no obligations whatever. If he arranged to meet a doctor in a private practice he must absolutely pay the set fee. If he is entitled to universal healthcare, he ought scrupulously to pay health insurance premiums. Every contract is based on a system of mutual rights and obligations.

If we were to consider a doctor's vocation, and the formal structure of the law and of the healthcare system, which determines the area of mutual relations between doctor and patient, there appear to be four types of possible attitudes that a patient can adopt towards a physician.

Indifference. The physician keeps his obligations towards the employer or client in a thorough manner, and the patient compensates him for his services directly (private practice) or indirectly (public or private healthcare insurance premiums). In this system there is practically no place for the feeling and duty of gratitude. The patient pays and expects something in return. It makes hardly any difference whether he pays the physician directly, or through social security or some private insurance fund. The physician's role is thus reduced to that of an ordinary service provider, and the patient's - to that of an ordinary client acquiring some medical service. It may be interesting to note that in some medical disciplines (e.g. rehabilitation, psychotherapy, nursing) there is nowadays less often talk of patients, and more frequently - of clients. This is because from the point of view of a market economy there is not the slightest difference between paying for some cosmetic service, on the one hand, and for rehabilitation or dental procedure, on the other.

Enmity or sense of wrong. Despite the fact that the physician performs his duties competently, scrupulously and lege artis, the patient is not satisfied with his conduct and usually accuses him of negligence or error. This is often followed by a lawsuit and demands for large compensation. In the United States, this practice has grown to epidemic proportions, and it is the general rule that every doctor is insured against such liability. Several years ago, the average annual cost of such insurance was over 100,000 dollars.

Apparent gratitude, or pseudo-gratitude. Despite the fact that the physician performs his duties competently, scrupulously and lege artis, 
working either in private practice or within the framework of a public healthcare system, the patient still believes that the doctor's efforts ought to be "appreciated" and that some "expression of gratitude" is in order, and failure to do so is seen as improper. Let us call this the waiter model of gratitude. Just as waiters and hairdressers are habitually tipped irrespective of the standard of their service, some people believe that the same goes for doctors. The venerable and noble vocation of the medical profession is thus reduced to simple service activity. It is worthwhile to stress that this practice, unheard of in western medicine, is apparently typical to all countries of the former soviet block. This is a peculiar approach which can in no way be justified by appealing to the dignity of the medical vocation and profession, irrespective of whether its root cause lies in the conduct of the nouveau-riche, unaware of how to behave and desiring to emphasise their social standing, or in compassion caused by consideration of doctors' difficult material situation, or else whether it is simply prudence dictated by past experience.

Gratitude proper. This is an attitude which can emerge in any healthcare system when the physician spontaneously and utterly selflessly does much more than he is obliged to do. In such case, the relation which binds doctor and patient is not a typical service provider-service recipient relation, but constitutes instead a specific moral relation sometimes termed love of the other. This is the kind of gratitude felt by the man wounded by robbers in the biblical parable of the Good Samaritan. Passing by, the priest, and then Levit, did not stop to help the injured man. It was only the Samaritan who tended the victim, though he had no obligation to do so. The same can occur in many clinical situations, when a doctor's exceptional conduct may indeed cause the patient to feel a binding need to express gratitude. The time, place and manner of such an expression encompass a whole range of behaviours - from a regular "thank you" to symbolic tokens. Choosing the right token is a matter of tact and good taste, and very much depends on social conventions and cultural patterns of the given society. In our cultural tradition what constitutes a typical "expression of gratitude" in the urban society is still a bouquet of flowers or a bottle of good alcohol, while in rural areas, according to the accounts of retired physicians, it was, until very recently, several eggs or a wad of butter. Occasionally, there appear in literature attempts to establish a morally acceptable monetary value of a token. I fear that there is little sense to this. For it constitutes nothing other than an attempt to institutionalize and legitimize a doctor's tip, much like the habitual $10 \%$ of the bill in western restaurants. The patient does indeed feel the need to express gratitude and I can see nothing wrong in his trying to do so in a more or less tactful manner. What is unacceptable is a doctor unwilling or unable to understand this need, or imposing on the patient some other "duties of gratitude". The art of giving is just as difficult as the art of receiving. Some gifts or tokens simply ought not to be offered, because they might offend or demean the physician, and some gifts or tokens should not be accepted, because they may, additionally, corrupt him. Yet it is impossible to set a clear and unambiguous boundary between what can and should be accepted, and what must not be under any circumstances. For some patients expenditure of even a few dollars for a small bouquet of flowers constitutes an important sacrifice, while others gladly and without any great effort can afford to present a doctor with a newest generation notebook in appreciation of his professionalism and considerate treatment. I have nothing against small and symbolic gifts. It is unacceptable, however, for it insults doctor's dignity, to accept money or any other expensive objects, favours or services, 
which could in any way make the doctor morally dependent on the patient.

\section{Pathology of gratitude}

A study of the so-called informal payments in the Polish healthcare system conducted in 2001 by Poland's Batory Foundation revealed that among the 1000 people questioned 356, or $36 \%$, declared that over the previous several years they did indeed offer doctors and other employees of the healthcare system money or other objects, in the majority of cases on more than one occasion. I do here not intend to present detailed results of this study - they are easily accessible on the internet. What is of interest to me is the moral psychology of those who give and those who take. For if it is indeed true that as much as $36 \%$ of the people interviewed had reasons to express authentic gratitude with a particular sum of money, a gift or favour, or in some other way, then this is evidence of our healthcare system's incredibly high moral standing. The $36 \%$ of the questioned patients not only felt gratitude, but also felt it necessary to express it tangibly to doctors and nurses. And if people pay more frequently and larger amounts in order to guarantee admission to a hospital, facilitate jumping queue for surgical procedures, or obtain some necessary certificates, then we are dealing with graft. The line between gratitude and corruption is exceedingly thin and difficult to establish, and the sole rational means of evaluation seem to be the examination of the givers' and takers' motives.

What I have in mind speaking of graft is a situation whereby a particular person (in the medical context this is the patient) or institution (e.g. a pharmaceutical company) is trying to gain favour with a person whose responsibilities, being a representative of a particular state institution, include deciding about the concession or distribution of certain scarce or particularly desirable resources, services or privileges. An attempt at corruption is successful when in a situation of conflict between, on the one hand, loyalty with regard to the interests of the represented national institution, and, on the other, the interests of a person or institution trying to gain favour, the official picks the latter at the cost of the former.

Therefore, a doctor who draws up a surgical procedure waiting list not on the basis of date of inscription or actual gravity of the patient's condition, but instead depending on patient's generosity, is a corrupt person. He is selling something that does not belong to him, concurrently violating the elementary principle of justice in the context of goods that we find especially important and desirable. Similar conduct is that of a health ministry official who, while preparing the list of refunded medications, lets himself be guided only by his own personal interest, and not by the good of the patients and the actual capacity and interests of the state. And yet, we sometimes hear, if there were no importunate and corrupting patients, there would be no graft. Let us then attempt to scrutinize the motives behind patients' conduct.

From the patient's perspective we can distinguish four important reasons for presenting a doctor with various kinds of gifts or tokens. These are: a) moral grounds, b) prudence and self-interest, c) false ideas about obligations towards the doctor, or about his situation, and d) conformism. Clearly, in the case of moral grounds there is possibility of a situation where the sole motive behind presenting the doctor with a gift is authentic gratitude. More frequently, however, the principal reason for trying to influence the doctor's decision is care and a feeling of responsibility for personal good and good of close ones. If I care about my personal health 
or the health and life of those close to me, it would be prudent to pay extra in order to secure a hospital bed or get the best surgeon in town to carry out the necessary procedure. In consideration of what I see as important moral values I decide to consciously break the law and offer a bribe to the doctor. A bribe is obviously an evil, but less so than loss of life or ill-health.

The motive of self-interest and prudence is illustrated by a situation where even before the treatment begins the patient hands the physician a certain amount, thus buying his favour and coercing him into a sort of "duty of gratitude". The doctor can only fulfil this obligation through treating the patient in a special manner. In the same way, by paying the doctor a hefty sum when treatment is over I secure good future contacts. Both cases are instances of graft.

The third motive can be succinctly illustrated with the phrase "I give, because he deserves it." And he deserves it for a number of reasons. First, because he is a doctor, and doctors just deserve respect and high regard, and additionally, as a doctor he exercises control over a special kind of goods and values - it is entirely up to him whether I shall receive them. Since a doctor treated me decently, I ought to express some gratitude. Second, since every doctor is also a human being, and people possess a natural need for gratitude, there is nothing wrong with satisfying this need. Third, in our country doctors work under such terrible material conditions that they ought to be helped and shown compassion, which can be done by supplementing their abhorrently low wages.

The conformist motive is expressed in the conviction that, since supplementary payments and corruption have become commonplace, it would be inappropriate to act otherwise. "I pay because everybody pays, and I'm no worse."
I believe that it has now become clear how apparently identical acts, or identical gifts, can in one case be an authentic expression of gratitude, and in another - instance of graft, or tactless, not to say boorish, behaviour. If a patient offers his doctor a gift, thanking for exceptional, I would say even Samaritan, care, he has every right to do so, and the doctor would do no wrong by accepting such a token. If, however, the principal motive behind the offered gift is an attempt to purchase the doctor's favour or subordinate him, then offering a token or a given sum of money becomes an act of manipulation. And any manipulation constitutes an infringement on our moral autonomy and undermines our trust, because it is based on falsehood and deception as to the manipulator's true goals and intentions. In such case, the patient is not really expressing gratitude; he is treating the doctor solely as a means to some personal ends, and I regret that a great many physicians see nothing wrong with such objectification of their profession. Appealing to the purported right to gratitude, the patient secures what he desires, from jumping queue to false health certificates necessary for, e.g. extension of a driver's license. Doctors, in turn, defending their alleged right to gratitude, do not seem to realize that in many instances in so doing they are defending a rather peculiar right to a tip. I have the impression that it would be something unbecoming for this noble profession if I were now seriously to consider whether doctors do in fact have such a right.

What is singular is that similar motives appear when we look at such practices from the doctor's perspective. By appealing to moral concerns one can try to demonstrate that a doctor ought not to offend the patient by refusing to accept an offered token, as the patient has not only the need, but also the right to express gratitude. One could indicate that due 
to exceptional training and skills, and the very nature of the exercised profession (because he really does save people's lives and health) a doctor has a special right to gratitude. Emphasis could be placed on prudence and self-interest ("I did not study laboriously for six years and continue with intensive additional training just to barely make ends meet"), or, finally, one could appeal to ubiquitous conformism ("I take, because everybody does").

\section{An attempt at diagnosis}

There are, I believe, three reasons which contribute to the pathology of gratitude and to the increasingly prevalent acceptance in our society of overtly corrupt behaviours.

In the moral sphere it is the emergence of a singular and false belief that both the patient and the doctor have "a right to gratitude". Let us, however, differentiate between two different things. The patient can indeed, under certain circumstances, feel the need of gratitude and pursue its concrete expression, as thanks for exceptional and especially considerate care -such behaviour is entirely natural and there is nothing wrong with it. A doctor, too, can at times feel a very natural need to receive gratitude for what he did for the patent. This is also understandable and fully justified. However, experiencing a very strong need to express or receive gratitude is by itself insufficient to prove the existence of some moral right to gratitude. It is one thing to claim the presence of some fact, and something else entirely to declare the existence of some moral right, and a moral right to the satisfaction of some need cannot be deduced from this need's existence. Is the biblical Samaritan really entitled to a moral right to expect some active expression of gratitude from the one he helped? Should he really arrive at the inn several weeks later, and say "I saved your life, now it is your turn"? Certainly, the
Samaritan's kind and selfless act requires reciprocation and it would be strange if the man rescued by him did not feel or in some way attempt to express gratitude. But it would be highly peculiar if several weeks later he would pay the Samaritan a visit saying "You saved my life. Here is my daughter. Take her. Let her be your slave. You cannot reject my token, because I have the right to express my gratitude." Does the Samaritan have a moral obligation to accept the gift, because to do otherwise would be to infringe upon the man's right to gratitude? Stating that we have a moral right to something is indeed a very strong claim. A right to something always implies the obligation to respect this something. The fact that I have the right to live means that others have an absolute obligation to refrain from doing anything that could imperil my life. The fact that in certain situations we do have the duty of gratitude does not, however, entail that there must exist a correlated right to gratitude, and that we can invoke this right in order to demand from other people compensation, reciprocity or tokens.

In the social sphere it is the disastrous organization of healthcare systems that remains the root cause of proliferation of graft. Good medical care is still a scarce, highly desired and often unattainable good. Note also that in multifarious private clinics, where the patient himself pays for consultation and treatment, there is no mention of any right to gratitude and no overtly corrupt procedures. The rules of distributing and ascribing services are clear and unambiguous - treat everyone according to the set price list. The patient knows exactly how much he has to pay, and may perhaps pay extra for "express service". He does not have to press or manipulate doctors or receptionists.

In the economic sphere the main reason for the escalating pathology of gratitude is the progressive pauperization of the medical profes- 
sion and the proliferation of the belief - proper to any free market - that money can buy everything, even special consideration and kindness of a doctor or nurse. If we add to this aggressive marketing of pharmaceutical companies and various activities of vested interests external to the medical profession, the patient gradually becomes justifiably convinced that in any conflict of interest between patient and doctor, the doctor tends to choose his own. The patient would thus be wise, caring above all for his selfinterest, not to forget about that of the doctor.

All this means that in our social consciousness the line between authentic feeling of gratitude and tipping, or bribery, between social conventions and acts contrary to law and morality, is gradually fading. 